\title{
Screening of Tuberose Cultivars against Leaf Spot (Alternaria polyanthi) and its Management
}

\begin{abstract}
Background: Tuberose flower has been found to be affected by various fungal and viral diseases which affect growth and cause loss in flower yield. Among them, leaf spot incited by Aternaria polianthi is an important fungal disease in tuberose. The incidence of the disease is common in the both single and double-type tuberose varieties due to prevalence of high rainfall and humid conditions. During survey it was found that the disease incidence was increasing gradually causing economic losses in Assam.

Methods: The field trial was carried out during kharif seasons $(2015-18)$ to test the efficacy of six fungicides against leaf spot of tuberose (Var. Local single petal) caused by Alternaria polyantha. Four sprays with fungicides at an interval of seven days starting from the first appearance of the disease symptom were done. Per cent disease incidence (\%) with growth parameters were recorded one week after the last spray. Another field experiment for screening the resistant genotypes was conducted using 11 tuberose genotypes during kharif seasons (2016-17 and 2017-18).

Result: Eleven tuberose cultivars (Bidhan Ranjani-1, Bidhan Ranjani-2, Arka Nirantara, GK-TC-4, Prajwal, Phule Rajani, Local Single, Local Double, Vaibhav, Suhashini and Shringer) were screened against leaf spot caused by A.polyanthi under natural field condition. None of the cultivars were found to be immune or resistant, while three cultivars viz., GK-TC-4, Bidhan Rajani-1 and Arka Nirantara showed moderate resistant reaction with recorded per cent disease incidence of $16.11,18.17$ and 18.71, respectively. Spraying with azoxystrobin, difenoconazole and a combo fungicide consisting of iprodione (25\%) + carbendazim (25\%), at $0.1 \%$ recorded lowest per cent disease incidence of $7.91,9.83$ and $11.85 \%$ compared to control (33.62 PDI) with per cent disease reduction of $70.59 \%$, $64.61 \%$ and $76.31 \%$, respectively.
\end{abstract}

Key words: Alternaria polyanthi, Chemical, Management, Screening, Tuberose.

\section{INTRODUCTION}

Tuberose (Polianthes tuberosa Linn.) is one of the most important ornamentals of tropical and sub-tropical areas (Biswas et al., 2002). In India, the commercial cultivation of tuberose is generally practiced in West Bengal, Karnataka, Maharastra, Tamil Nadu, Haryana, Punjab, Gujarat, Rajasthan, Andhra Pradesh including Assam (Biswas et al., 2002; Khan and $\mathrm{Pal}, 2001$ ). It is commercially cultivated for cut and loose flower trade and also for the extraction of its highly valued natural flower oil (Mishra et al., 2008). This crop has been affected by various fungal and viral diseases which affect growth and cause loss in flower yield. Among them, leaf spot incited by $A$. polianthi is an important fungal disease (Mariappan et al., 1977) in tuberose. The disease is manifested in the form of brown specks on leaf tip or margin which gradually attain round to oval shapes measuring $10-30 \mathrm{~cm}$ in length and $4-5 \mathrm{~cm}$ in diameter. Later, spots coalesce and develop typical blight symptom. In India, leaf spot in tuberose incited by $A$. polyanthi was first reported from the locality of Coimbatore (Mariappan et al., 1977) and in the succeeding period once again from the same state, Tamil Nadu (Muthukumar et al., 2007). Another type of leaf blight/tip burn due to Phoma spp has also been reported (Panja et al., 2016). The incidence of the disease is common in the both single and double-type tuberose varieties due to prevalence of high rainfall and humid conditions. During
Horticultural Research Station, Assam Agricultural University, Kahikuchi, Azara, Guwahati-781 017, Assam, India.

Corresponding Author: N. Mazumder, Horticultural Research Station, Assam Agricultural University, Kahikuchi, Azara, Guwahati781 017, Assam, India. Email: nmazumder66@gmail.com

How to cite this article: Mazumder, N., Borah, S.K. and Deka, K.K. (2021). Screening of Tuberose Cultivars against Leaf Spot (Alternaria polyanthi) and its Management. Agricultural Science Digest. DOI: 10.18805/ag.D-5289.

Submitted: 28-12-2020 Accepted: 24-08-2021 Online: 11-09-2021

survey it was found that the disease incidence was increasing gradually causing economic losses in Assam. As the available information on the source of resistance to this foliar disease and its management are very limited, hence, an attempt was made to investigate the efficacy of different fungicides and screening of tuberose cultivars for resistance sources for the management of leaf spot disease of tube rose under field condition.

\section{MATERIALS AND METHODS}

The field experiment was conducted in randomized block design with seven treatments and three replications during kharif seasons (2015 -18) at the experimental field of Horticultural Research Station AAU, Kahikuchi, in sick field 
where the leaf spot disease naturally occurs every crop season. The treatments were comprised of mancozeb $75 \%$ WP $(0.2 \%)$, chlorothalonil $75 \%$ WP $(0.2 \%)$, tricyclazole $75 \%$ WP $(0.1 \%)$, iprodione $(25 \%)+$ carbendazim $(25 \%)$ WP $(0.1 \%)$, difenconazole $25 \%$ EC $(0.1 \%)$, azoxystrobin $23 \%$ SC $(0.1 \%)$ and control. Tuberose bulbs cv. Single Petal Local were planted during March in the plots of $2.0 \mathrm{~m} \times 2.8 \mathrm{~m}$ at spacing $30 \mathrm{~cm} \times 30 \mathrm{~cm}$. The plants were sprayed with fungicides four times at an interval of seven days starting from the first appearance of the disease symptom, mostly at flower stalk initiation stage. Per cent disease intensity was recorded one week after the last spray. Six clumps from the center of each plot were considered to compute the per cent disease index (PDI) on the basis of 0-4 scals (Harsfall and Henbeeger, 1942). Flower stalk (no. $/ \mathrm{m}^{2}$ ), weight of the freshly harvested stalk $(\mathrm{g})$ and the length of the flower stalk (cm) were also recorded. The data of per cent disease incidence were subjected to angular transformation and analysis of variance was calculated out (Snedecor and Cochran, 1967). Economic of fungicide application was computed on the basis of economic returns from flower yield and cost of fungicidal treatments (Hugar et al., 2009-10).

\section{Screening of tuberose cultivars under field condition}

The field experiment for screening the resistant genotypes was conducted during kharif seasons (2016-17 and 2017-18) at the experimental field of Horticultural Research Station AAU, Kahikuchi. A total of eleven tuberose cultivars were grown in randomized block design with three replications in the plots of $1.8 \mathrm{~m} \times 1.5 \mathrm{~m}$ at spacing $30 \mathrm{~cm} \times 30 \mathrm{~cm}$. The observation on per cent disease index (PDI) was calculated as above, at harvest when the disease was developed to its maximum extent. Further, the degree of resistance of tuberose cultivars was ascertained by placing the cultivars in different categories of resistance and susceptibility as per the method proposed by Pathak, et al. (1986) as follows.

Scale to indicate degree of resistance against leaf spot of tuberose

\begin{tabular}{lcl}
\hline Disease severity & Category & Reaction \\
\hline$<5$ & 0 & Immune \\
$5-10$ & I & Resistance \\
$11-20$ & II & Moderately resistance \\
$21-40$ & III & Moderately susceptible \\
$41-60$ & IV & Susceptible \\
$>61$ & V & Highly susceptible \\
\hline
\end{tabular}

\section{RESULTS AND DISCUSSION}

Data presented in (Table 1) indicated that the fungicidal spray could manage the disease adequately. Timely initiation of fungicidal spray schedule, starting the first spray at the appearance of disease symptom was found to be effective in reducing leaf spot of tuberose significantly. Although, disease control as high as $76.31 \%$ was achieved in azoxystrobin $(0.1 \%)$ but it proved to be costlier as compared to the other treatments which recorded third highest benefit cost ratio (6.75). Maximum flower stalk production $\left(51.20 / \mathrm{m}^{2}\right)$, flower stalk length $(85.93 \mathrm{~cm})$ and effective number of bulbs $\left(103.53 / \mathrm{m}^{2}\right)$ were obtained in the plots treated with azoxystrobin $(0.1 \%)$ as compared to $33.03 / \mathrm{m}^{2}, 80.70 \mathrm{~cm}$ and 68.15 nos. $/ \mathrm{m}^{2}$ in case of control and showed $55.05 \%$ increase in flower stalk yield over control (Table 2). Effectiveness of azoxystrobin (0.1\%) against Alternaria leaf spot of tuberose were also reported (Anonymous, 2012; Mazumder et al., 2016).In in-vitro study it was reported that Azoxystrobin (1000 ppm) could inhibit about $86.81 \%$ mycelia growth of $A$. Polianthi inciting leaf spot in tuberose (Naga Lakshmi et al., 2018). Singh and Singh (2006) also reported about the effectiveness of azoxystrobin against $A$. alternata causing blight of tomato. Good control of Alternaria leaf spot of Chinese cabbage by the application of azoxystobin was observed by Robak (1998).

On the other hand, considering the economic analysis, spraying of difenconazole and a combo fungicide consisting of iprodione (25\%) + carbendazim (25\%) at the rate of $0.1 \%$ were found most effective since they registered higher benefit cost ratio of 7.28 and 7.03 with higher per cent disease control of $70.59 \%$ and $64.61 \%$, respectively. The effectiveness of difenconazole $(0.1 \%)$ and iprodione $(25 \%)$ + carbendazim (25\%) (0.1) in reducing leaf spot of tuberose was reported earlier (Sharma and Bhattacharjee, 2002; Anonymous, 2004 and Mazumder et al. (2016). In tomato, early blight (A.solani) was effectively managed by the application of Iprodione (0.2\%) (Prasad and Naik, 2003). Significant differences in the production of number of flower stalk (per sq. m), number of bulb $\left(\mathrm{m}^{2}\right)$ and length of flower stalk $(\mathrm{cm})$ had been observed as influenced by different treatments (Table 2). Flower yield (49.55 and $\left.41.19 / \mathrm{m}^{2}\right)$, number of bulb $\left(95.90\right.$ and $\left.93.60 \mathrm{~m}^{2}\right)$ and flower stalk length $(85.90$ and $84.81 \mathrm{~cm})$ were recorded from the plots treated with difenconazole and iprodione (25\%) + carbendazim (25\%) and which also showed 50.01 and $24.70 \%$ increase in flower yield over the control. Increase in flower yield and other qualities have been assumed to be due to the effective control of the pathogen and further spread of the disease.

Data on leaf spot severity showing the relative reaction of different tuberose cultivars are presented in (Table 3). All the cultivars screened against the Alternaria leaf spot were found to be infected by the disease. None of the eleven cultivars were free from the disease. Therefore, no cultivar could be placed under the category immune or resistant (category 0 and I). However, three cultivars viz., GK-TC-4, Bidhan Rajani-1 and Arka Nirantara recorded per cent disease incidence of $16.11,18.17$ and 18.71, respectively and were placed under moderately resistant reaction (category II). The remaining eight tuberose cultivars viz., Local Single (35.89\%), Shringer (33.35\%), Bidhan Ranjani -2 (31.86\%), Vaibhav (30.24\%), Suhashini (29.62\%), Prajwal (26.61\%), Phule Rajani (23.03) and Double Local (20.49\%) were found moderately susceptible (category III). Similar 

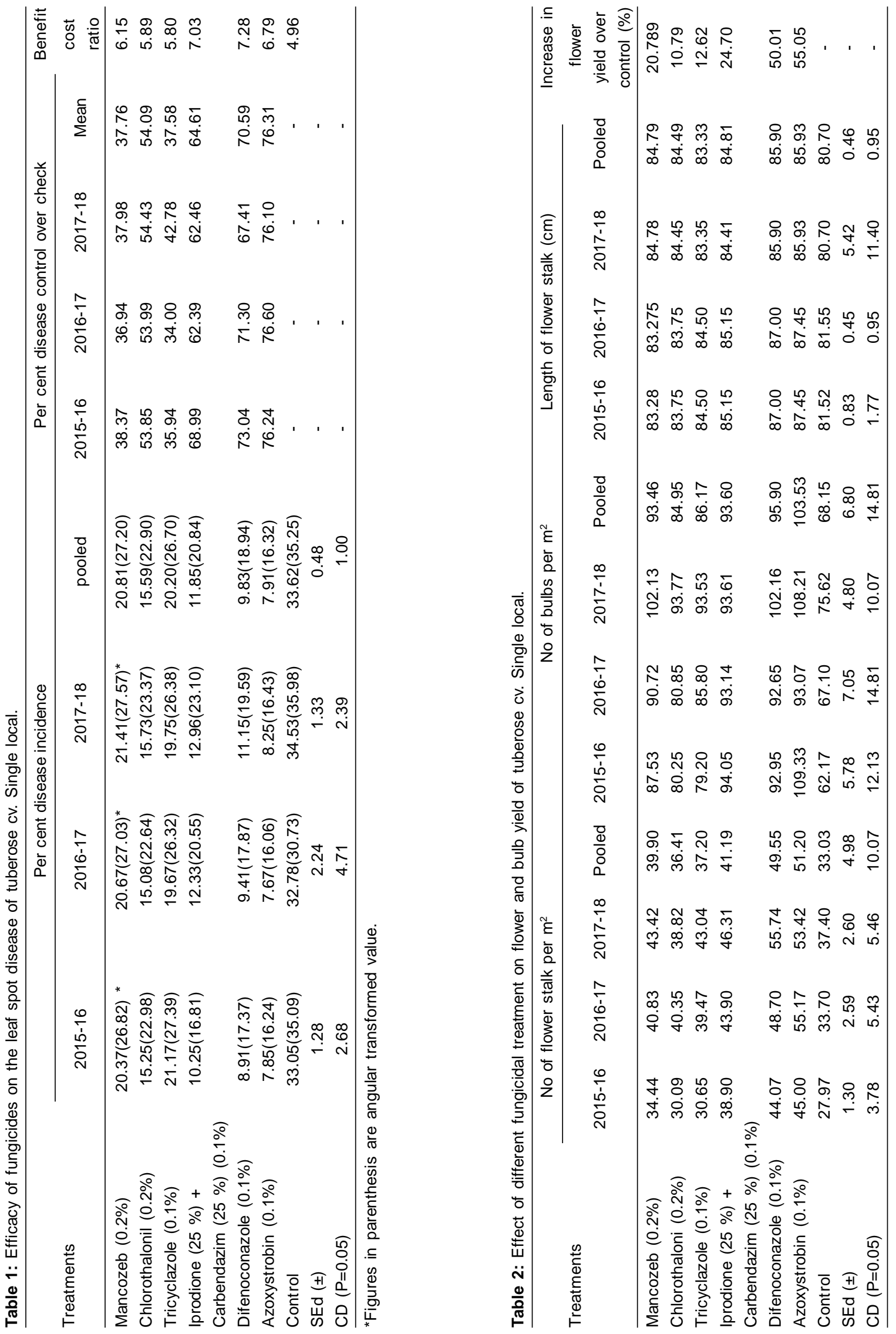
Table 3: Reaction of tuberose varieties against Alternaria Polianthi causing leaf spot under field condition.

\begin{tabular}{lcccc}
\hline \multirow{2}{*}{ Varieties } & \multicolumn{3}{c}{ Per cent disease incidence (\%) } & Reaction \\
\cline { 2 - 4 } & $2016-17$ & $2017-18$ & Mean & Moderately resistance \\
\hline Bidhan Rajani-1 & $16.11(23.55)^{*}$ & $20.22(26.60)^{*}$ & 18.17 & Moderately susceptible \\
Bidhan Rajani-2 & $31.61(33.87)$ & $32.11(34.58)$ & 31.86 & Moderately resistance \\
Arka Nirantara & $18.09(25.15)$ & $19.33(26.07)$ & 18.71 & Moderately resistance \\
GKCT-4 & $15.00(22.62)$ & $17.22(25.25)$ & 16.11 & Moderately susceptible \\
Phule Rajani & $22.76(28.48)$ & $23.30(28.86)$ & 23.03 & Moderately susceptible \\
Prajwal & $27.67(34.70)$ & $25.56(30.98)$ & 26.61 & Moderately susceptible \\
Local Single & $35.61(36.61)$ & $36.17(36.98)$ & 35.89 & Moderately susceptible \\
Local Double & $20.26(26.74)$ & $20.72(27.07)$ & 20.49 & Moderately susceptible \\
Vaibhav & $32.70(34.87)$ & $27.78(31.77)$ & 30.24 & Moderately susceptible \\
Suhashini & $31.14(33.91)$ & $26.11(30.72)$ & 29.62 & Moderately susceptible \\
Shringer & $32.65(34.84)$ & $34.05(35.69)$ & 33.35 & - \\
SEd $( \pm)$ & 2.12 & 1.72 & - & - \\
CD $(\mathrm{P}=0.05)$ & 4.63 & 3.75 & & - \\
\hline
\end{tabular}

results on screening tuberose cultivars on Alternaria leaf spot were reported by Naga Lakshmi et al. (2018).

\section{CONCLUSION}

None of the cultivars tested showed resistant reaction (category 0 and I) while three cultivars viz., GK-TC-4, Bidhan Rajani-1 and Arka Nirantara showed moderate resistant reaction with recorded per cent disease incidence of $16.11 \%$, $18.17 \%$ and $18.71 \%$, respectively (category II). Rest cultivars viz., Bidhan Ranjani-2, Prajwal, Phule Rajani, Local Single, Local Double, Vaibhav, Suhashini and Shringer were placed under moderately susceptible category (category III). Systemic fungicides viz., azoxystrobin, difenconazole and a combo fungicide consisting of iprodione $(25 \%)+$ carbendazim (25\%) at $0.1 \%$ resulted lowest per cent disease incidence of $7.91 \%, 9.83 \%$ and $11.85 \%$, respectively compared to control (33.62 PDI). Economic analyses revealed effectiveness of difenconazole followed by iprodione + carbendazim and azoxystrobin with highest $\mathrm{B}: \mathrm{C}$ ratio of $7.28,7.03$ and 6.79 , respectively.

\section{ACKNOWLEDGEMENT}

The authors are thankful to the Chief Scientist, Horticultural Research Station, AAU, Kahikuchi, Guwahati-781 017 for his constant help and providing necessary facilities to carry out this investigation.

\section{REFERENCES}

Anonymous (2004). Progress Report, AICRP (Floriculture), Directorate of Floricultural Research, ICAR, New Delhi-12, 2004-05, pp xiii.

Anonymous (2012). Progress Report, AICRP (Floriculture), Directorate of Floricultural Research, ICAR, New Delhi-12, 2011-12, pp xii.

Biswas, B., Naveen Kumar P. and Bhattacharjee, S.K. (2002). In: Tuberose, AICRP on Floriculture, Tech Bull No. 21, iii pp.
Horsfall, J.G. and Henberger, J.W. (1942). Measuring magnitude of a defoliation diseases of tomato. Phytopathology. 32: 226-232.

Hugar, S.V., Hosamoni, V., Pradeep, S. and Hanumanthasway, B.C. (2009-10). Evaluation of new chemical molecules for the management of Scirpophagus incertulus Walker in aerobic rice. Int. J. PI. Protn. 2: 205-208.

Khan, M.R. and Pal, A.K. (2001). Plant parasitic nematode associated with Tuberose (Polianthes tuberosa L.) in West Bengal. Ann. PI. Prot. Sci. 9: 304-306.

Mariappan, V., Babu, K. and Kandasamy, T.K. (1977). A leaf spot disease of tuberose (Polianthes tuberose L.) caused by new species of Alternaria. Curr. Sci. 46(9): 311.

Mazumder, N., Bora, S.K. and Hatibarua, P. (2016). Management of leaf spot (Alternaria Polianthi) of tuberose through fungicides. Agril. Sci. Digest. 36(3): 250-252.

Mishra, A., Tiwary, A.K. and Sharma, J.P. (2008). Effect of bio-control agent and chemicals on root rot and yield attributes in tuberose (Polianthes tubarosa Linn.) cultivars Calcutta Double. J. Ornamental Hort. 11(1): 41-44.

Muthukumar, A., Bhaskaran, R., Eswaran, A. and Kumar, M. Raj (2007). Studies on biochemical properties of healthy and leaf spot infected tuberose plants. Ind. J. Hort. 46(2): 190-193.

Naga Lakshmi, T., Madhumati, C, Nagaraju, R and Sreedhar, D. (2018). Screening of tuberose cultivars and effect of fungicides against tuberose leaf spot caused by Alternaria polianthi. Int. J. Pure. App. Biosci. 6(2): 232-237.

Panja, B.N., De, A., Mandal, M. and Saha, J. (2016). First report on leaf tip blight disease of tuberose (Polyanthes tuberosa L.) caused by new Phoma sp., Phoma mondouriensis from West Bengal. J. Mycopathological Res. 54(1): 171174.

Pathak, D.P., Singh, A.A., Despandey, A. and Sridhar, T.T. (1986). Sources of resistance to purple blotch in onion. Vegetable Sci. 13(2): 300-303.

Prasad, Y. and Naik, M.K. (2003). Evaluation of genotypes, fungicides and plant extracts against early blight of tomato caused by Alternaria solani. Ind. J. PI. Prot. 31(2): 49-53. 
Robak, J. (1998). Recent advance at integrated protection of cabbages against diseases with attention to club root (Plasmodiophora brassicae), Alternaria leaf spot (Alternaria spp.) and grey mold (Botrytis cinerea). Progress-in-PlantProtection. 38(1): 119-123.

Sharma, P. and Bhattacharjee, S.K. (2002). Plant protection in ornamental crops. AICRP on Floriculture, ICAR, New Delhi-12, Technical Bulletin No.19, 64 pp.
Singh, P.C. and Singh, D. (2006). In vitro evaluation of fungicides against Alternaria alternata. Ann. PI. Protec. Sci. 14(2) 500-502.

Snedecor, W.G. and Cochran, W.G. (1967). Statistical Methods. The lowa State University Press, Ames, lowa, 593 pp. 